\title{
Analysis of Farmers' Access to and Perception of Extension Service Delivery in Borno State, Nigeria
}

\author{
Idrisa, Y.L., M. M.Gwary, and B.O.Ogunbameru \\ Department of Agricultural Economics and Extension \\ University of Maiduguri, Borno State, Nigeria.
}

\begin{abstract}
This study analysed access to and perception of private extension delivery by farmers in Borno state. Primary data were collected from 128 farmers selected using multi-stage sampling technique. A five point Likert type scale was developed and used to elicit information on respondents' attitude toward private extension service delivery. The collected data were analysed using descriptive statistical techniques such as frequency counts and percentages. Result indicated that majority (63.3\%) of the respondents were between the ages 36 and 50 years with high proportion (70\%) cultivating not more than 4 hectares of land. The study further revealed that majority (84\%) had access to public extension service with only $43 \%$ having access to private extension. Most of the respondents expressed positive attitude towards privatization of extension services. Based on the findings of the study, it was recommended that rural areas should be provided with social and economic infrastructure and private extension services be encouraged in rural areas.
\end{abstract}

\section{INTRODUCTION}

The importance of agricultural extension in agricultural development is widely acknowledged, particularly in developing countries such as Nigeria where the. Wanga (1999) opined that in most developing countries, agriculture is the main source of livelihood. In addition, Nambiro et. al. (2006) observed that since Kenya's independence in 1963, agricultural extension services have largely been provided by government. This is equally true in Nigeria where public participation has been into all aspects of this economy including direct agricultural production (Adedoyin, 2004; Ozor and Madukwe, 2004).

The current trend in extension is tilting towards reduced emphasis on uniform message as provided by the Training and Visit (T\&V) system but rather to involve other stakeholders (including farmers and private sector) in gaining more ground (Robert and Rober,2003). Private participation or outright privatized extension has been the subject of widespread discussion by those considering the challenges of providing an efficient agricultural extension system for farmers in developing coutries(Kidd et. al., 2000; Rivera, 2001; Katz, 2002). Privatized extension can take many forms and it has become clear that it does not represent a simple undifferentiated alternative to the public extension system it is expected to replace (Anderson and Crowder, 2000).

Although the private extension initiatives offer many opportunities for large scale farmers, there is less certainty about the implication for the resource -poor farmers, whose connection to, and command of, market is much more tenuous 
(Robert and Robert, 2003). Such observation is much stronger given that many of the resource-poor farmers have been poorly served even by the public sector extension (Ozor and Madukwe, 2004); Omotayo and Arokoyo, 1990). Does a call for privatization of extension imply any greater hope for them? Can private extension initiatives serve the needs of commercial farmers in order to strengthen agricultural market forces desirable economic development and accommodate the resource-poor farmer? In other words, can private extension outfit guarantee accessible and efficient services to all categories of farmers by redressing the uses of defective capital structure, excessive bureaucracy, inappropriate technology, management and blatant corruption which seem to characterize public extension out fit? Theses are the questions that are to be addressed by this writeup

\section{Objectives}

The main objective of this study was to determine farmers' access to and perception towards private extension service in Borno state. The specific objectives were to;

(i) determine the socio-economic characteristics of farmers in the study area;

(ii) determine the types of extension service providers in this study area;

(iii) determine accessibility to private extension service by farmers with study area;

(iv) determine the farmers' attitude toward private extension service delivery in the study area.

\section{METHODOLOGY}

The study was conducted in Borno State, Nigeria. The state has three Agricultural Zones namely Biu, Bama and Kukawa Zones. Bama Zone was purposively selected for the study because the zone was created at the on-set of the Agricultural Development Programme (ADP) System in the former Borno State which now form Borno and Yobe States. The zone also serves as the state ADP headquarters since Maiduguri the state capital which hosts the ADP headquarters is also located in this zone. The zone is made up of eight (8) Extension Areas, (16) Extension Blocks and 128 Extension Circles. Using multistage random sampling technique, 4 Extension Areas were randomly selected out of the 8 Extension Areas in the Zone. In the second stage of the selection, 2 Extension Blocks were randomly selected from each of the 4 selected Extension Areas giving a total of 8 Extension Blocks used for the study. Each of the 8 Extension Blocks has 8 Extension Circles, giving a total of 64 Extension Circles used for the study. From each of the 64 Extension Circles, 2 farmers were randomly selected giving a total of 128 farmers used for the study.

Interview schedule was used to obtain information from the respondents. Information was sought on the sources of extension information available (private or public) to the farmers. A five point Likert type scale was developed and used to elicit information on the appropriateness of public and private extension outfit in the provision of services to farmers, as used by Ozor and Madakwe (2004). 


\section{Journal of Agricultural Extension \\ Vol. 12 (1) June, 2008}

\subsection{RESULTS AND DISCUSSION}

\subsection{Socio Economic Characteristics of Respondents}

Table 1 revealed that majority (63.3\%) of the respondents fall between 36 and 50 years of age, with about $70 \%$ having educational qualification not beyond the primary school level. This means that more than half of the respondents are youth and have received certain level of educational training. These have implications for demand driven extension as Nambiro, et al (2006) put it that age and literacy level have a significant impact on the likelihood of farmers seeking and receiving demand driven extension service, which is essential in privatized extension service. The study also showed that most of the respondents are small-holder farmers with about $70 \%$ cultivating not more than 4 ha of land. The same thing applies to income. Half $(50 \%)$ of the respondents earn not more than $\$ 200,000: 00$ per annum. Both farm size and level of income positively affect accessibility to extension service as previous studies (Nambiro, et al, 2006; Alax, et al; 2002; Byerlee and Echeverria, 2002) opined that private agricultural extension is intimately associated with large scale commercial farming. In a particular study in Germany (Robert and Robert, 2003), the proportion of farmer seeking extension advice fell from $80 \%$ to $13 \%$ when extension service was privatized and the majority those who patronize the advisory services were farmers cultivating over 500ha. Onu (2006) also reported that farm size significantly influence both farmers' adoption decision and accessibility to extension service. This implies that majority of the farmers in the study area may not be able to afford extension service under the privatized regime since a vast majority have small land holding. The finding is also particularly implicative for Nigeria, with more than half of her citizen living below the poverty line and more than $70 \%$ of the farmers operating at peasanty level (Olowoye, 2004).

Table 1 also shows that $68 \%$ of the respondents are members of registered farmers' associations. This can facilitate their accessibility to private extension as the effect of membership of farmers' cooperative society on accessibility to private extension services appreciably high (Birkhaeuser, 1991). Also, more than $70 \%$ of the respondents reported that they reside at a distance of more than $10 \mathrm{~km}$ from the closest source of private extension services. Households that are located further away from town centers, which would require extension agents to spend more time and fuel resources to access are less likely to be visited (Nambiro, et al, 2006). In a related study, Carney (1998) opined that, farmers living in areas with decentralized extension services are more likely to access such services. This coincides with the general opinion that when farmers have extension opportunities open to them, they are better placed to actively participate in seeking such service. However, the result provides an indication that a vast majority of the resource-poor farmers in Nigeria, who are mostly resident in the rural areas may not benefit equitably from such advisory services despite the raging debate on its benefit. 
TABLE 1: Distribution of Respondent According to Socio-economic Characteristics

\begin{tabular}{|c|c|c|}
\hline Socio-economic Variable $(x)$ & Frequency (n) & Percentage (\%) \\
\hline \multicolumn{3}{|l|}{ Age (years) } \\
\hline Less than 35 & 31 & 24.0 \\
\hline $36-50$ & 81 & 63.3 \\
\hline Above 50 & 16 & 12.7 \\
\hline \multicolumn{3}{|l|}{ Educational Level } \\
\hline No formal education & 48 & 29.7 \\
\hline Primary school education & 50 & 39.1 \\
\hline Secondary school education & 37 & 28.9 \\
\hline Tertiary education & 03 & 2.3 \\
\hline \multicolumn{3}{|l|}{ Farm Size (ha) } \\
\hline Less than 2 ha & 32 & 25.0 \\
\hline $2-4$ ha & 58 & 45.3 \\
\hline $5-7$ ha & 25 & 19.5 \\
\hline More than 7 ha & 13 & 10.2 \\
\hline \multicolumn{3}{|l|}{ Level of Income (Per annum) } \\
\hline Less than $\mathrm{N} 100,000=00$ & 12 & 9.4 \\
\hline $\mathrm{N} 100,000-\mathrm{N} 200,000=00$ & 52 & 40.6 \\
\hline $\mathrm{N} 200,000-\mathrm{N} 300,000=00$ & 38 & 29.7 \\
\hline More than $\mathrm{N} 300,000=00$ & 26 & 20.3 \\
\hline \multicolumn{3}{|c|}{ Membership of farmers corporative } \\
\hline Yes & 87 & 68 \\
\hline No & 41 & 32 \\
\hline \multicolumn{3}{|c|}{$\begin{array}{l}\text { Distance from source of private } \\
\text { extension service }(\mathrm{km})\end{array}$} \\
\hline$<5 \mathrm{~km}$ & 15 & 11.7 \\
\hline $5-10 \mathrm{~km}$ & 21 & 16.4 \\
\hline $11-15 \mathrm{~km}$ & 48 & 37.5 \\
\hline $16-20 \mathrm{~km}$ & 32 & 25.0 \\
\hline$>20 \mathrm{~km}$ & 12 & 9.4 \\
\hline
\end{tabular}

Source: Field Survey, 2007.

\section{Type of Extension Services Received and Crop Grown}

Table 2 revealed that more than eighty $(80 \%)$ percent of the respondents had access to public extension service while less than half $(43.8 \%)$ had access to public extension service. Out of those who had access to private extension service, about $80 \%$ are resident in the urban towns of Maiduguri and Bama, while most of them are either large scale farmers or cash crop farmers mostly engaged in Dry season farming. This also portrays the biased nature of private extension services in favor of the large scale and/or urban based farmers.

Result on the type of farming also indicates that $68 \%$ of the respondents are engaged in the production of food crops mainly millet, sorghum and groundnuts, while about half $(50.8 \%)$ are engaged in cash crop production, mainly cowpea, onion, pepper and carrot. Here also, most of the farmers patronizing private extension services are cash crop farmer in the urban/peri-urban centers. Omotayo and Arokoyo (1990) pointed out that generally, most private organization do not provide extensive 


\section{Journal of Agricultural Extension}

Vol. 12 (1) June, 2008

service on a country-wide basis. They concentrate their services in areas which have favorable physical environment and satisfactory infrastructure. Again, private organizations are often involved in the promotion of cash crops at the expense of food crops. Relevant examples are cotton and tobacco whose production have received vigorous boost over the years due to services provided by private extension services (namely AFCOT and NTC). This trend will further frustrate the attempt to up grate the subsistence food production.

TABLE 2: Distribution of respondents according the type of extension service received (public or private)

\begin{tabular}{lcc}
\hline \multicolumn{1}{c}{ Type Of Extension Service } & Frequency & Percentage (\%) \\
\hline Public & 108 & 84 \\
Private & 56 & 43.8 \\
Type of farming & & \\
Food crop farming & 87 & 68.0 \\
Cash crop farming & 65 & 50.8 \\
\hline
\end{tabular}

Multiple responses existed sum of $\%>100$

Source: Field Survey, 2007.

\section{Farmers' Access to Private Extension Services}

Among the few that had access to private extension services, about half $(42.9 \%)$ had the access on weekly basis, and another $35.7 \%$ accessed the service at least once every fortnight (Table 3 ). This also justifies the biased nature of private extension service. The fact that more than three-quarters $(78.6 \%)$ of the eligible population could access the service highly contrasts with the average accessibility of public extension service where more than half $(58 \%$ had access to extension service once in a month (Idrisa and Ogunsbameru, 2004).

Table 3: Distribution of Respondents according to access to private extension services

\begin{tabular}{lccc}
\hline $\begin{array}{l}\text { Access to private } \\
\text { extension service }\end{array}$ & Frequency & $\begin{array}{c}\text { Percentage (\%) as of } \\
\text { those who have } \\
\text { access (56) }\end{array}$ & $\begin{array}{c}\text { Percentage as of } \\
\text { whole sample (128) }\end{array}$ \\
\hline Weekly & 24 & 42.9 & 18.8 \\
Once in two weeks & 20 & 35.7 & 15.6 \\
Once in a month & 8 & 14.3 & 6.3 \\
Irregular & 4 & 7.1 & 3.1 \\
No access & 108 & 192.9 & 84.0 \\
\hline
\end{tabular}

Source: Field Survey, 2007 


\section{Attitude of Respondents toward Private Extension Services}

Analysis of the attitude of farmers toward private extension services indicates that most of the farmers are in support of privatizing agricultural extension services. For instance, more than half $(53.1 \%)$ of the respondents indicated that privatization of extension will bring about higher frequency of contact between farmers and extension agents. This may be because if farmers actually contribute to extension services, they will watch out to ensure that extension agents justify the farmers' investment by visiting them more regularly. The percentage distribution of respondents who strongly agree or agree that there is going to be improvements in provision of appropriate technical information, timely and affordable input accessibility and accountability in extension delivery following privatizations are $62.5 \%, 79.7 \%$ and $84.4 \%$ s respectively as can be seen in Table 4 . All the above can be explained by the fact that privatization will lead to participation of farmers in monitoring of extension activities with a view of seeing that they get value for their resources. This further corroborates earlier studies (Farrington, 1994; Rolling, 195 Coldevin, 2000) that an environment characterized by dwindling government budget and waning donor interest lead to significant decline in public extension services while Suleiman (2003) suggested that one major advantage of privatized extension service is that it involves broad based and knowledgeable participation from farmers themselves in terms of planning and monitoring. Similarly, Schwartz (1994) opined that privatized extension functions better than the public extension because extension assumes that the farmers will articulate their needs, they manage and enforce contract with private extensions provider and also evaluate the result of such contract. Ideally, this strategy not only eases the delivery of extension messages to farmers, but also makes extension service more appropriate and responsive to their needs. 


\section{Journal of Agricultural Extension \\ Vol. 12 (1) June, 2008}

TABLE 4: Distribution of respondents according to the attitude towards privatization of extension services

\begin{tabular}{|c|c|c|c|c|c|}
\hline \multirow[t]{2}{*}{ Statement } & \multicolumn{2}{|c|}{ Responses } & \multicolumn{3}{|c|}{ Categories } \\
\hline & SA & $A$ & UD & D & SD \\
\hline $\begin{array}{l}\text { Privatization can bring } \\
\text { higher frequency of } \\
\text { contact with extension } \\
\text { agents }\end{array}$ & $38(19.7)$ & $30(23.4)$ & $40(31.2)$ & $15(11.7)$ & $5(4.0)$ \\
\hline $\begin{array}{l}\text { Privatization will bring } \\
\text { more appropriate } \\
\text { technical information }\end{array}$ & $45(25.2)$ & $35(27.5)$ & $2(1.6)$ & $36(28.1)$ & $10(7.8)$ \\
\hline $\begin{array}{l}\text { Privatization will bring } \\
\text { about timely and } \\
\text { affordable input } \\
\text { accessibility }\end{array}$ & $34(26.6)$ & $68(53.1)$ & $15(11.7)$ & $10(7.8)$ & $1(0.8)$ \\
\hline $\begin{array}{l}\text { Privatizations will bring } \\
\text { about accountability and } \\
\text { efficiency in extension } \\
\text { service }\end{array}$ & $50(39.1)$ & $58(45.3)$ & $10(7.8)$ & $4(3.1)$ & $6(4.7)$ \\
\hline $\begin{array}{l}\text { Privatization will lead to } \\
\text { deprivation the resource } \\
\text { poor farmers }\end{array}$ & $15(11.7)$ & $10(7.8)$ & $40(31.2)$ & $50(39.1)$ & $13(10.2)$ \\
\hline
\end{tabular}

N.B. Values in bracket are percentages.

Source: Field Survey, 2007

About half $(49.3 \%)$ of the respondents also disagree that privatization of extension will lead to deprivation of the resource-poor farmers. Although Suleiman and Van den Ban (2003) are of the opinion that the demise of public extension may be seen as abandonment of the cause of the resource-poor farmers, probably because agricultural extension has come to be so firmly associated with the public sector, particularly in the developing countries, the view of the respondents indicates that such fears are unwarranted. The result also supports earlier findings (Roberts and Robert, 2003; Katz, 2002) that, private extension alternatives have been debated and developed precisely because of concerns about the poor performance of public extension, including its inability to consistently deliver useful information to the resource-poor farmers.

\section{CONCLUSION}

Majority of farmers aged between 30 to 50 years, with low levels of education and cultivating less than 4 hectares of land. Incomes among the farmers were generally low, with about half earning not more than \#200,000.00k per annum. It is also the conclusion of this study that private extension is more popular with large scale or cash crop farmers, most of who are urban-based. If deliberate steps are not taken, the rural-based peasant farmers, who produce bulk of the agricultural products used in this country may be deprived. However, among those who had access to the private 
extension services, frequency of contact with extension agents and delivery of appropriate technologies have been enhanced significantly, with majority having contact with extension agents at least once in a fortnight. Overwhelming majority of the respondents also have positive attitude towards privatization of extension services because they believed that privatized extension service can, and will bring about farmers' participation in extension planning and monitoring. proffered:

From the analyses of the study, the following recommendations are hereby

1. Private extension should be encouraged to serve food crop farmers who are essentially subsistent in operation, at least at the initial stage so as to expose them to the benefits of private extension.

2. Private extension outfits should be encouraged to reach out to rural areas where majority of the farmers live and work, rather than limiting their services to the urban and peri-urban.

\section{References}

Adedoyin,F.S (2004) policy issues and legislation in agricultural extension delivery in a democratic and parag economy. Proceedings of the $9^{\text {th }}$ Annual national conference of the agricultural extension society of Nigeria $8^{\text {th }}-11^{\text {th }}$ March

Alex, G. , Zisp, W. and Byerlee, D. (2002).' Rural Extension and Advisory Services: New Direction'. Rural Strategy Background paper, No. 9, Washington D.C.

Anderson . J and Crowder . L.V (2000) This present and Future of public sector extension in Africa. Contracting out or contracting in? The public administration and development 20:373-384.

Birkhaeaeuser, D., Everson, R.E. and Feder G. (1991). The Economic Impact of Agricultural Extension: A Review. Economic Development and Cultural Change, 39: 607-650.

Byerlee, D. and Echeverria, R. (eds) (2002). Agricultural Research in an Era of Privatization. $\mathrm{CABI}$ Publishers, Wallingford, UK.

Coldevin, G. (2000) participation communication and adult leaning for rural development Rome FAO.

Farrington, J. (1994) public sector agricultural extension: there after structural adjustment? Natural resource perspective N0. 2 London : Overseas development institution.

Idrisa, Y.L. and Ogunbameru, B.O. (2004). Assessment of Extension Agents' Performance Under the Unified Agricultural Extension Services in Borno State. Journal of Agro-Technology and Extension vol.4 No.1. (In press).

Katz, E (2000). Innovative approaches to financing extension for agricultural and natural resources management. Conceptual considerations and analysis of experience. SWISS centre for agricultural extension.

Kidd, A., Lamers, J. Ficarelli, P.and Hoffman, V. (2000). Privating agricultural extension: Journal of Rural Studies vol. 16.pp381-401. 


\section{Journal of Agricultural Extension \\ Vol. 12 (1) June, 2008}

Nambire, E., Omiti, J. and Muguruievi. L. (2006). Decentralization and Access to Agricultural Extension Access to agricultural conference of agricultural economics, Gold coast, Austria August 12-18.

Olawoye, J.F. (2004). Agrcultural extension and poverty alleviation in a democratic and deregulated economy. Proceedings of the $9^{\text {th }}$ Annual National Conference of the Agricultural Extension Society of Nigeria, held at the Obafemi Awolowo University, Ile-Ife, March, $8^{\text {th }} 11^{\text {th }}$.

Omotayo, A and Arokoyo T. (1990). Increased Private Sector Participation in Agricultural Extension in Nigeria : How it May Affect the Resource-Poor Farmers. Paper presented at the $3^{\text {rd }}$ National Farming Systems Research Network Workshop, Calabar, August, $13^{\text {th }}-16^{\text {th }}$.

Ozor, N. and Madukwe, M.C., 2004). Strategic for increasing private sector participation in funding agricultural extension services in Nigeria : The professionals reaction in Enugu state national council on privatization NCP(2001). Privatization handbook ( $3^{\text {rd }}$ edition). Abuja NCP secretariat: $114 \mathrm{pp}$.

Rivera, W. (2001). Agricultural and rural extension worldwide oppions for institutional reform in developing counties. Rome F.A.O.

Robert, C. and Robert. T. (2003). Changing Incentives for Agricultural Extension. A review of Privatized Extension Network No. 132.

Robert, C. and Robert, t.(2003). Changing incentives for agricultural extension- A review of privatized extension network NO 132.

Rolling, W. (1995). What do you think of extension? A comparison of there models of extension practice. AEADD bulletin reading, U.K: University of Reading .

Shwartz, L.A. (1994). The Roles of Private Sector in Agricultural Extension: Economic Analysis and Case Study. Agricultural Research and Extension Newsletter No. 48.

Suleiman, R. (2003).' Private Extension in India : Recent Initiatives'. Agricultural Research and ExtensionNetwork Newsletter, No. 47.

Suleiman, R. and Van den Ban A.W.(2003). 'Funding and Delivering Agricultural Extension in India '. Journal of International Agricultural and Extension Education, 10 (1) 2-7.

Wanga, E. (1999). Key note address on New Perspective in Rural Extension. Regional Refresher International Course in rural extension (ICRE)on : challenges and prospects Exertion University . $21^{\text {st }}$ Nov- $3^{\text {rd }}$ Dec. 